\title{
Integrated Project Delivery (IPD) Research Trends
}

\author{
Zahra Kahvandi ${ }^{1}$, Ehsan Saghatforoush ${ }^{2}$, Mahdi Alinezhad ${ }^{3}$, and Farimah Noghli ${ }^{4}$ \\ ${ }^{1}$ MSc Student, Department of Project and Construction Management, Mehralborz Institute of Higher Education, \\ Tehran-Iran. E-mail: z.kahvandi@gmail.com \\ ${ }^{2}$ Assistant Professor, Department of Project and Construction Management, Mehralborz Institute of Higher Education, \\ Tehran-Iran. E-mail: e.saghatforoush@mehralborz.ac.ir (corresponding author). \\ ${ }^{3} \mathrm{MSc}$ Student, Department of Project and Construction Management, University of Tehran, Tehran-Iran. E-mail: \\ m alinezhad@ut.ac.ir \\ ${ }^{4} \mathrm{MSc}$ Student, Department of Project and Construction Management, Mehralborz Institute of Higher Education, Tehran \\ -Iran. E-mail: farimah.noghli@gmail.com
}

\author{
Project and Production Management \\ Received February 10, 2017; received revisions May 1, 2017; June 21, 2017; accepted June 22, 2017 \\ Available online July 11, 2017
}

\begin{abstract}
Integrated Project Delivery (IPD) is introduced as a vibrant approach to enhance project implementation, having particular position in recent studies among construction researchers. This study analyzes the research trends on the field of IPD to provide an appropriate vision for future researchers in this specialized field. While so far no comprehensive research has been done in this field, this study provides a comprehensive review of existing studies through in-depth literature review method. This research evaluates studies conducted in the field of IPD, which is a basis for future researchers to improve conditions of IPD implementation in different countries. For that this study Using library studies, the trend of researches conducted on various concepts and domains during various years, has been investigated. Future studies can simply use the outputs of this research to shape their research flow on establishing continuing progress of IPD. The data obtained from descriptive analyses are illustrated quantitatively, followed by comprehensive analyses and discussion of the results. Moreover, this study concluded that during recent years, the trend of studies conducted about IPD has increased, particularly articles examined challenges. In the next step, more studies have been performed in the field of construction. Those articles are preferred that have evaluated principles, challenges, and solutions for resolving barriers. Proper IPD implementation facilitates enhanced share of information and early identification of stakeholders through a proper timing as vital keys to realize objectives of the construction projects, reduce risks, and increase the chance of project success.
\end{abstract}

Keywords: Integrated project delivery, trend, implementation, descriptive analysis.

\section{Introduction}

In today's world, the construction industry is becoming more complex and specialized day by day, yet inappropriate function causes loss of various resources in it (Lichtig, 2006). Therefore, selecting noble approaches for enhancing project implementation is very significant (Kent and Becerik-gerber, 2010). Integrated Project Delivery (IPD) is one of the new approaches of project implementation that has developed in some countries during recent years, to improve traditional implementation methods. In some countries such as USA, some contracts are written and performed in this regard (AIA, 2012). This method provides realization of main objectives of the project through improving factors such as time and cost and creating conditions for open and efficient communications among project stakeholders, and creates win-win fields (Chan et al., 2004).

When it comes to studying trend of a special issue in science, it definitely includes evaluating a set of effective changes in a specific industry (Erkessousi, 2010). Such studies at a glance, provides comprehensive information about a specific topic to the researcher (Kahvandi et al., 2016). Studies that explore trend of an issue can be implemented in all industries and time periods, and the main objective of them is collecting data from several and diverse resources (Abdirad and Pishdad-Bozorgi, 2014a). In studies, in which the trend of a special issue in a certain time period is evaluated, an overall screening is done and usually total information are studied yearly. During recent years, various studies have been conducted in the field of IPD. IPD is investigated from different aspects ( $\mathrm{Li}$ and Taylor, 2011). But the common thing among all of them is that most of these studies have tried to introduce the IPD method as a comprehensive approach (Collins and Parrish, 2014). Considering the fact that available literature has deeply insisted on the significance of IPD consideration in the construction industry, collecting and classifying information about the trend of IPD is very important (Thomsen, 2009). So far, no comprehensive study has been done in the field of IPD trend (Kahvandi et al., 
2016), and this is the main reason for unfamiliarity of project stakeholders with such an executive system in the construction industry (Bach, 2014). This study is conducted to provide a comprehensive study for determining the trend of performed studies in the field of IPD. Moreover, this study concluded that during recent years, the trend of studies conducted about IPD has increased, particularly articles examined challenges. In the next step, more studies have been performed in the field of construction. Those articles are preferred that have evaluated principles, challenges, and solutions for resolving barriers. The next section points to the background of IPD researches and its achievements.

\section{Literature Review}

For the first time, comprehensive definitions of IPD were offered by American Institute of Architects (AIA). According to this definition, IPD includes presence of all key factors of the project from outset in an integrated manner, and using their experiences and constructive cooperation in a multilateral contract to have a more successful project and participation in risk and reward for all stakeholders in project life cycle (AIA, 2007). Conducted studies in the field of IPD, according to their extent in different fields, include various cases. In this regard, various contracts are written to support this emerging method in the USA, among them is AIA E202 contract, but because of existence of governing rules and conditions in the construction industry, particularly public construction (Fish, 2011), sometimes these contracts are used as attachment to public conditions (Garcia et al., 2014). It is because the IPD implementation requires several contractual agreements and changing governing rules (Ilozor and Kelly, 2012). Using IPD principles to compile contracts based on time and budget objectives is very important, so that it can develop training people and forming a common framework in team (Ghassemi and Becerik-Gerber, 2011). The IPD method includes different principles; 1) mutual respect and trust which introduces team work as a very significant tool for project success. 2) Mutual benefits and rewards which states that depending on agreed conditions among all project stakeholders, rewards should satisfy all of them. 3) Open communication, which reduces the claims in projects. 4) Early goal definition that results in creativity, and strengthens motivation. 5) Organization and leadership that is delegated to qualified and competent people. 6) Intensified planning that leads to proper organization of time. 7) Collaborative innovation that because of open interlocution produces creativity. 8) Early involvement of key participants that insists on bringing the key factors in the project from the beginning. 9) Using updated technology, and advanced communications are considered as important factors of IPD implementation (AIA, 2007).

One of the important factors in implementing the IPD method is good leadership, trust, respect, suitable work relations and high degree of team participation (El Asmar and Hanna, 2012). Trust and respect are achieved over time and via mutual cooperation; in fact trust is the pre-requisite of cooperation among stakeholders (Clark, 1997). Having mutual trust can successfully complete complex duties in a common environment (Wong and Cheung, 2004).

However, structure of organizations and culture inconsistencies and values are the major barriers of using this method (El Asmar et al., 2013; Becerik-Gerber et al., 2010). Conducted case studies in the field of IPD have shown that in most cases, budget and schedule targets are achieved in it with a high percent (Hassan, 2013). In the Cathedral Hill Hospital project in San Francisco, United States, one of the existing barriers was determining final costs in the project, and the suggested solution was the entrance of employer, providers of resources in the project, before the beginning of construction (AIA, 2012). One of the important factors is early participation of contractors and design team. It is because participation in risk and reward sharing is among motivational factors for quite all contractors (Hanks, 2015). Gallstedt defines motivation as a driving force supports team members' attempts to achieve common team goals. Motivation changes during project lifecycle. Moreover, Gallstedt specifies team motivational factors during different phases of project lifecycle:

Primary phases:

- People deliver the result of their jobs and receive rewards.

- $\quad$ Encouragement for professional skills.

- Job counseling should be provided to manage the job.

Executive phases:

- An opportunity for improving the experience.

- The responsibility of achieving milestones has been assigned to people, and the opportunity to prove the skill is created.

- People should be encouraged to solve their problems and share rewards.

Final phases:

- $\quad$ People try to understand how the new project helps their progress.

- $\quad$ There is an opportunity for proving professional skills through problem solving methods (Gallstedt, 2003).

Considering comparisons between projects in which the IPD method is applied with those projects used other approaches, significant statistics are obtained in criteria such as quality, managing changes and communication. Quality is one of the most important criteria that have been increased by implementing IPD. Project quality is the amount of needs met by project's existing qualifications. In other words, products of expected performance should be verified during the project. Verifying project quality is performed through procedures such as quality guarantee, quality control, and project and product inspection (El Asmar et al., 2015). In the IPD-based projects, changes have been less and speed of performance has been more, and also project delivery time has been improved significantly. The results of case studies are very useful, particularly to help informed decisions for project shareholders (El Asmar et al., 2013). The IPD method has also had significant role in cost criteria, especially in energy and sustainability savings (Azhar, 2014). In this method, because of predictions and presence of several stakeholders from the beginning phase of initial studies, estimations are much closer to reality (Lee et al., 2013). Due to available rules in public projects, the IPD method 
is implemented rarely, but according to the conducted studies, the idea of existence of a regulatory agency is introduced as a useful way in this field. One of the advantages of IPD is sharing building information in project life cycle that is provided to stakeholders for various and key decision makings (Kelly and Ilozor, 2013).

So far several studies have been done in the field of IPD, but more basic studies are needed to describe IPD value at the macro level (Salami, 2012). Conducted studies have not been focused on the manner of IPD trend. Thus in this study, the IPD trend has been evaluated to advance administrative goals and facilitate future studies. No comprehensive study has been done in the field of IPD trend (Kahvandi et al., 2016). Its method will be described in the next section.

\section{Research Methodology}

Research methodology is a recognition tool and also a tool for production of equation. From another perspective, it can be said that research methodology is a regular tool needed for all researches. There is a logic that separates regular research from irregular researches in all arenas, and confirms its being scientific and methodical (Bast, 1994). In this study, research methodology is as literature review. In literature review, the researcher studies about a certain issue based on various resources. Such studies are also free from hypothesis. In other words, literature review is considered as a descriptive study (Bazargan, 1997). In other words, hypotheses of literature review are in fact those questions that are proposed in research objectives section and are replied at the end of the study (Mohadesi, 1997). Then, collected data are described as qualitative analysis.

Collected articles are from different scientific databases, and totally conference articles are less. More attention has been paid to articles placed in more reliable databases. All investigated articles are in the field of construction. In several searches with diverse keywords, total number of collected articles was 156 , which these articles have been published from 2001 to 2016 in different countries. It was early years of the present century that researchers paid attention to innovating and developing modern methods to improve conditions by the help of IPD and the first definitions of this new method was proposed since 2001. Evaluating this volume of articles provided valuable results for researchers to pave the road for future studies. Through careful study of texts of these articles from different aspects and analyzing obtained data, several tables and statistics are extracted, which are shown in next section.

\section{Data Analysis}

Analysis of data is explicating and describing meanings inherent in data. Interpretation leads to finding comprehensive and clear understanding of meanings and concepts. Throughout data interpretation, conflicts and contradictory contents and/or the way of mutual relations or events show themselves. Collected data are of qualitative kind. Matthew and Mills (Matthew and Miles, 1984) have proposed several methods to show qualitative research data. Among these methods we can refer to figures, tables, networks, and matrices. Through these tools, data are offered in an organized shape in a way that is available to researchers easily (Brennan, 2011). The volume of obtained data in this study was so extensive, thus some criteria considered to have more accurate and useful classifications. First, classification of all articles collected from various databases is presented from 2001 to 2016 in the Table 1.

This table demonstrates the extent of IPD scope in different scientific databases. Addressing the issue of IPD, due to its comprehensiveness, has made researchers to consider it from different aspects. Particularly in recent years, a high volume of such articles has been published in reliable scientific databases. Evaluating scientific databases was proposed with high sensitivity, so that the provided outputs can maintain its comprehensiveness. In some databases, according to the subject desired to the researcher, i.e. IPD in construction, not other fields, the number of found articles was significant. As it is presented in the above table, the ASCE database, by publishing 85 articles, has the highest number of articles in this specific field, and this indicates too much attention of this database to most recent research subjects such as IPD. The list of 156 collected articles based on their subject and resources has been classified in Table 2 .

Following, the Fig. 1 is obtained by classifying articles based on the number of published articles in different countries with the IPD subject from different perspectives based on needs and necessities of its implementation. The mentioned countries are in different parts of the world. It indicates that IPD, despite being introduced in less than one decade, has had a significant growth in the world (Sive, 2009). Among the mentioned countries, presence of developing countries is notable. Some of these countries are still in the beginning of the path of IPD implementation, because changing the construction contracts is one the important factors of IPD implementation. This factor requires changing certain rules. Therefore, IPD implementation restriction is natural in those countries, and changing rules requires a long time. As it is found from the findings, in less than one decade, most of the countries of the world have tried to implement IPD. Among these, the number of published articles by developing countries is also notable and shows their attention to this method. But considering the legal restrictions in these countries, proper implementation of this method has not still been successful (Ghassemi and Becerik-Gerber, 2011).

Classifying published articles based on different countries is important, because over time, and by implementation of this method in these countries, its various aspects will become more complete and richer. This issue indicates more focus of researchers in these countries in future studies, which according to the results obtained from USA in the field of developing contracts and producing different articles, it has a high statistics. European countries, following USA, have evaluated IPD in different fields. Asian countries, due to their advances in recent years, have evaluated IPD partially. High number of producing scientific content about IPD completely confirms this issue that USA is among the first countries that developed integrated contracts based on the IPD method. Therefore, it is not surprising that this country is considered at the top of countries producing content related to this noble method.

IPD has been applied in some countries such as the United States since early days of IPD birth. In some of the real projects, it has led to significant results such as more 
accurate prediction of project costs, more accurate compliance of implementation timing, better risk management through clarification of objectives, reducing technical complexities through combining stakeholders, and preference in marketing (AIA, 2012).

The Fig. 2 shows dispersion of articles during different years from early years of emerging this method till now. At the initial years of twentieth century, information in this field has not been completed, though in some partial cases, suggestions and points from researchers are proposed. By developing a guide for IPD implementation by the AIA in 2007, attention to IPD trend has been increased. Such growing trend can be extracted from the growing number of published articles on this field since 2007 till now. This figure indicates degree of importance of IPD in recent years. The number of published articles on IPD has had a significant rise in 2014. It seems that from 2007 to 2014, most of studies were about introducing the IPD approach, and a few articles refer to case studies that implemented this newly introduced method in the construction projects; thus, from the beginning of 2015 , due to saturation of articles addressed the importance and necessity of implementing IPD, the volume of published articles has reduced.

According to evaluation of published articles in 2016, researchers have done more comprehensive comparisons between traditional methods and IPD, through investigating quantitative results obtained from conducted projects by the aid of IPD, and the results obtained from these researches are provided to owners of the construction industry, in the form of a model. Through evaluating and classifying knowledge content available in articles, the Fig. 3 was obtained, which indicates the number of researches in this field in different areas of knowledge maturity.

Considering the conducted investigations by different authors, it seems that IPD articles can be grouped into five major domains shown in the Fig. 3. At the beginning of the years of IPD introduction, the focus of many articles was on the foundations of this newly born delivery system. IPD foundations state its implementation principles, and their application challenges. BIM is one of the important technical tools for IPD implementation, which has been addressed by researchers and the construction industry owners significantly in the recent years. In many of the articles reviewed (Ashcraft, 2009), BIM and IPD have been evaluated together. IPD implementation has been done in some countries and some researchers have published the results of their practical IPD implementation in the form of reports (Thomsen, 2009). In some of the countries, IPD implementation has been faced with different barriers, but there are various solutions for them considering the existing rules. In some of these articles, solutions are examined completely and comprehensively in order to implement IPD (Ghassemi and Becerik-Gerber, 2011).

This figure indicates that challenges in implementing IPD in the construction industry have allocated a large portion of researchers' studies in recent years to themselves. With the emergence of modern methods, minds of people tend toward extracting shortages of these methods unconsciously, and in this regard, it has been tried to find advantages, disadvantages and barriers in implementing modern methods. Evaluating basics of IPD, as a new method, which its principles should be defined in different aspects, is at the second place of attention of researchers, because with the development of this newly born method in the construction industry, developing countries try to extract principles for implementing that. The IPD method includes different principles; 1) mutual respect and trust. 2) Mutual benefits and rewards. 3) Open communication. 4) Early goal definition. 5) Organization and leadership. 6) Intensified planning. 7) Collaborative innovation. 8) Early involvement of key participants. 9) updated technology, and advanced communications (AIA, 2007; Sommer et al., 2013). Barriers of implementing IPD in different countries are at the next place of importance. Some of the barriers includes, the challenge of selecting compensation for financial losses (Rached et al., 2014), lack of coordination in payment systems (AIA, 2012; Becerik-Gerber et al., 2010; Rached et al., 2014), tend to use conventional contractual methods (Nejati et al., 2014), disinclination of stakeholders to participate in a project with common interests (Ghassemi and Becerik-Gerber, 2011; Nejati et al., 2014), lack of integrated interoperability because of lack of necessary technology (Becerik-Gerber et al., 2010; Ghassemi and Becerik-Gerber, 2011; Rached et al., 2014), lack of mutual trust among stakeholders (AIA, 2012). Evaluating the challenges and their corresponding solutions paves the road for proper IPD implementation. Since BIM is considered as an efficient tool for implementing IPD principles, and finally articles, which state implementation of IPD in different countries in a way, are at the last place of importance. It should be mentioned that what is evident in the articles related to implementing IPD, is high degree of saving in project costs. The reason of it is early participation of key project stakeholders, including owner, designer, contractor, and supplier (Ghassemi and Becerik-Gerber, 2011). 'Selecting Appropriate Technology' is one of the IPD's nine principles. BIM is one of the important tools for resolving this principle. In some countries, studying and evaluating IPD has led the researchers to study how to implement BIM (Bao, 2013). Appropriate definitions of IPD for industry owners and offering solutions to remove the barriers to IPD implementation and evaluating the differences of the samples of it, can be effective in IPD implementation in different situations. Of the reviewed papers, 13 articles have addressed the issue of IPD implementation. These statistics indicate that IPD implementation stage still has several problems and barriers, including the rules and regulations governing the construction industry of different countries (Al Subaih, 2015). In the United States, the private section has had significant growth in use of IPD in action however the public sector still faces with major problems using that (Collins and Parrish, 2014).

Studies about IPD have been done in different domains; these applied domains are presented in the Fig. 4. In this figure, the construction projects include road construction, tunnels, dams, watering, building bridges, public transportation, water and wastewater treatment systems, ports, airports, oil, gas, and water pipelines projects, etc. Particularly, building projects also include office building, commercial towers, hospital facilities, schools, banks, etc. The miscellaneous group are those not included in any of the aforementioned classes that authors have placed these projects in the form of miscellaneous projects, such as: modernization, refineries, and petrochemical complexes, and natural gas treatments. 
This figure shows that the construction industry has benefited from the IPD method more than other industries, as the number of studies performed in the construction industry is much more than other fields. From the bank of collected data, 20 articles have targeted building projects, particularly. And other studies, nearly 15 studies, include other fields. The construction domain contains big projects with huge capital for implementation, which will have important role in implementing these projects during the conducted IPD researches. The mutual benefit and reward principle, which is one of the 9 principles of IPD implementation, is applied very well in the projects introduced in these articles. Building projects in the field of IPD implementation have had fewer shares. Generally, the construction industry usually enjoys updated technologies and tools later than other industries (Ghassemi and Becerik-Gerber, 2011). Miscellaneous projects that here includes modernization, refineries and petrochemical complexes, and natural gas treatment projects, have also less share in IPD implementation, because in these fields, despite high potentials of IPD implementation, no comprehensive studies have been done. On the other hand, the existing contracts do not allow fast changes in the contract shapes.

In the Fig. 5, articles are classified based on whether they are covering qualitative results, researches associated with quantitative results or studies considered just as definitions, concepts and principles of IPD. The difference of the investigated cases in this figure is in the way that in some of the articles, researchers have just examined IPD itself in order to introduce it to the industry owners. These definitions include IPD implementation principles, advantages, barriers, and feasibility of its implementation, etc. Projects that have taken advantage of IPD over the past few years and their results have been analyzed qualitatively, are in the category of qualitative studies. In some of the articles, based on the performed comparisons and the obtained results from IPD implementation, the results have been raised quantitatively. By using the facts and figures, various statistics of projects have been presented in some of these articles.
This figure shows that articles focusing on definitions, concepts and principles of the IPD are more than other types of articles. Evaluating quantitative results of projects, provides very valuable information for researchers in different fields, thus some of the articles have tried to achieve this point through making comparisons and extracting different statistics. Qualitative results are at the next category of this classification, which have been done in the USA more than other countries.

Proper IPD introduction to the industry for its easy implementation is of great significance. Because only after such an in-depth introduction, entering a new era of delivering the project can be possible, and then it will be followed by basics of changing the rules and encouraging investors and owners of the construction industry to real IPD implementation. According to the performed investigations reported in this article, so far, more quantitative studies on IPD implementation have been done rather than the qualitative ones (Rahim et al., 2015). As comparing facts and figures and estimating the profit of real IPD implementation have had more of importance to the researchers; this encourages investors to use IPD more than before (AIA, 2012).

The number of studies conducted in different countries, indicates extension of IPD implementation in the construction industry all over the world. In this study, the number of conducted studies in different years was analyzed. According to the intention of the researcher, comprehensive issues in the construction industry were classified. Degree of importance of each of them was proposed based on degree of attention of researchers to them. Challenges of IPD implementation were among cases considered more than others. In the Fig. 4, it is stated that IPD focus is on basic domains of the construction industry. Evaluating the results of case studies has always been toward informed choices of investors in private and public sections. However, to this day, contribution of private section in this field has been more significant. In the next section, what extracted from these studies is discussed.

Table 1. Bases presenting articles and the number of found articles in them (from 2001 to 2016)

\begin{tabular}{cc}
\hline Database Name & Number of papers \\
\hline ASCE & 85 \\
ELSEVIER-Science Direct & 31 \\
AIA & 4 \\
SMPS Foundation & 2 \\
Springer Link & 1 \\
Wiley Online Library & 7 \\
ProQuest & 3 \\
Dissertation & 5 \\
Civilica & 6 \\
Taylor and Francis & 7 \\
IEEE & 0 \\
Cumin CAD & 0 \\
CIB-Library & 0 \\
EBSCO & 0 \\
EMERALD & 0 \\
\hline
\end{tabular}


Table 2. List of articles based on their subjects (from 2001 to 2016)

\begin{tabular}{|c|c|c|}
\hline Number & Categorize Topics & References \\
\hline 1 & Case Study & $\begin{array}{l}\text { (Kihong Ku, 2009), (Basu et al., 2009), (Mossman et al., 2010), (Barben et al., 2010), } \\
\text { (Cohen, 2010), (Brady and Davies, 2010), (Jackson, 2011), (Singleton and Hamzeh, } \\
\text { 2011), (Tillmann et al., 2012), (AIA, 2012), (Franz and Leicht, 2012), (Hampson and } \\
\text { Kraatz, 2013),(Mollaoglu-Korkmaz et al., 2014), (Garcia et al., 2014), (Kraatz et al., } \\
\text { 2014), (Hall et al., 2014), (Do et al., 2015), (Bilbo et al., 2015), (Bygballe et al., 2015), } \\
\text { (Pishdad-Bozorgi, 2016), (Harrison et al., 2016). }\end{array}$ \\
\hline 2 & Implementation & $\begin{array}{l}\text { (Michael et al., 2010), (Becerik-Gerber et al., 2010), (Fish, 2011), (Fish and Keen, } \\
\text { 2011), (Lee, 2013), (Rahman et al., 2013), (Mihic et al., 2014), (Abdirad and } \\
\text { Pishdad-Bozorgi, 2014), (Azhar, 2014), (Rached et al., 2014), (Ma et al., 2014), (Kim } \\
\text { and Teizer, 2014), (Francom et al., 2014). }\end{array}$ \\
\hline 3 & Principles & $\begin{array}{l}\text { (Tenah, 2001), (Tan, 2006), (Thomsen, 2007), (AIA, 2007), (McKew, 2007), } \\
\text { (Integrated Workshop, 2007), (Wang, 2008), (Hatem, 2008a), (Hatem, 2008b), } \\
\text { (Thomsen, 2009), (Sive, 2009), (Harty and Laing, 2009), (Smith et al., 2009), } \\
\text { (Perlberg, 2009), (O’Connor Jr., 2009), (Ashcraft, 2009), (Kent and Becerik-gerber, } \\
\text { 2010), (Volker and Klein, 2010), (Chan et al., 2010), (Shane and Gransberg, 2010), } \\
\text { (Klotz and Horman, 2010), (Darrington and Lichtig, 2010), (Duke et al., 2010), } \\
\text { (Treiblmaier and Filzmoser, 2010), (Cox et al., 2011), (Nofera et al., 2011), (Baiden } \\
\text { and Andrew DF Price, 2011), (Brennan, 2011), (Arjmandi, 2011), (Salami, 2012), } \\
\text { (Overbeek et al., 2012), (Jayasena and Senevirathna, 2012), (Wamelink et al., 2012), } \\
\text { (Tatum and Luth, 2012), (Hickethier et al., 2013), (Macdonald and Mills, 2013), } \\
\text { (Rawat and Divekar, 2014), (Lee et al., 2014), (Azhar et al., 2014), (Shahhosseini, } \\
\text { Hajarolasvadi, et al., 2014), (Shahhosseini, Shakeri, et al., 2014), (Seed, 2014), (Roe, } \\
\text { 2014). }\end{array}$ \\
\hline 4 & IPD Barriers & $\begin{array}{l}\text { (Chan et al., 2004),(Ballobin, 2008),(Ghassemi and Becerik-Gerber, } \\
\text { 2011),(Shahhosseini, 2013),(Sommer et al., 2013),(Lee et al., 2013),(Nejati et al., } \\
\text { 2014),(Collins and Parrish, 2014),(Zhang and Li, 2014),(El Asmar et al., 2015). }\end{array}$ \\
\hline 5 & IPD Benefit & $\begin{array}{l}\text { (Hasan, 2010), (Gokhale, 2011), (El Asmar and Hanna, 2012), (Alp and } \\
\text { Vonwerssowetz, 2013), (Korkmaz et al., 2013), (Hassan, 2013), (Jones, 2014), } \\
\text { (Perdomo and Cavillin, 2014), (Bach, 2014), (McCurley and Powell, 2015), (Rahim } \\
\text { and Nawi, M. N. M. Nifa, 2015), (Anonymous, 2015), (Cody, 2015), (Hanna, 2016), } \\
\text { (Kahvandi et al., 2016). }\end{array}$ \\
\hline 6 & IPD and BIM & $\begin{array}{l}\text { (Autodesk, 2008), (Wickersham, 2009), (Hess, 2009), (Caldwell et al., 2009), } \\
\text { (Franklin and Tobin, 2010), (Erkessousi, 2010), (Manning, 2012), (Ilozor and Kelly, } \\
\text { 2012), (Bryde et al., 2013), (Kelly and Ilozor, 2013), (Pishdad-Bozorgi et al., 2013), } \\
\text { (Parfitt et al., 2013), (Kiani and Khalili Ghomi, 2013), (Cooley and Cholakis, 2013), } \\
\text { (Bao, 2013), (Lu et al., 2014), (Monteiro et al., 2014), (Nawi et al., 2014), (Son et al., } \\
\text { 2015), (Jalaei and Jrade, 2015), (Lee et al., 2015). }\end{array}$ \\
\hline 7 & $\begin{array}{l}\text { IPD and Other } \\
\text { Topics }\end{array}$ & $\begin{array}{l}\text { (Chan et al., 2003), (Dal Gallo et al., 2009), (Xue et al., 2010), (Raisbeck et al., 2010), } \\
\text { (Ashcraft, 2011), (Darrington, 2011), (Voss, 2012), (Jung et al., 2012), (Lahdenperä, } \\
\text { 2012), (Goldberg et al., 2012), (Kulkarni et al., 2012), (El Asmar et al., 2013), (Zhang } \\
\text { et al., 2013), (Abdirad and Pishdad-Bozorgi, 2014b), (Azari et al., 2014), (Popic and } \\
\text { Moselhi, 2014), (Volk et al., 2014), (Hornstein, 2014), (Perdomo et al., 2014), } \\
\text { (Turkulainen et al., 2014), (Sanz-Calcedo et al., 2015), (Abdirad, 2015), (Brioso, } \\
\text { 2015), (Al Subaih, 2015), (Yalcinkaya and Singh, 2015), (Hanks, 2015), (Alrashed and } \\
\text { Asif, 2015), (Cao et al., 2015), (Lu et al., 2015), (Qiang et al., 2015), (Zhang et al., } \\
\text { 2015), (Pishdad-Bozorgi and J.Beliveau, 2016), (Pishdad-Bozorgi and J. Beliveau, } \\
\text { 2016). }\end{array}$ \\
\hline
\end{tabular}




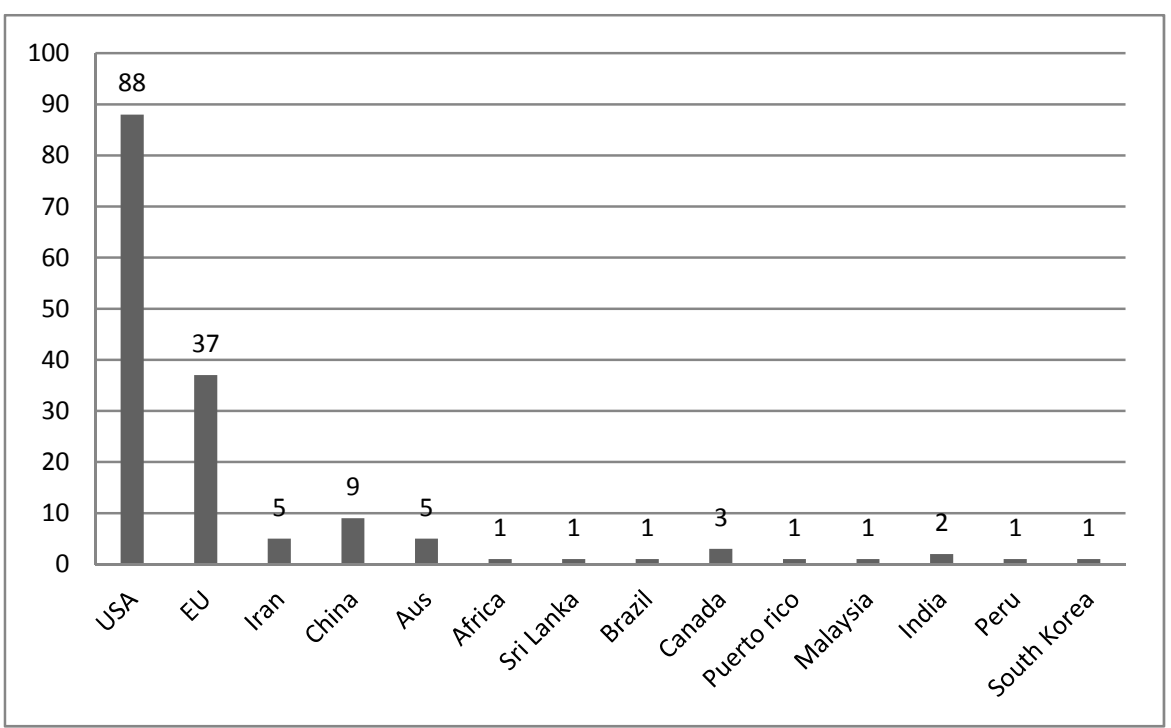

Fig. 1. Countries presenting articles and the number of found articles

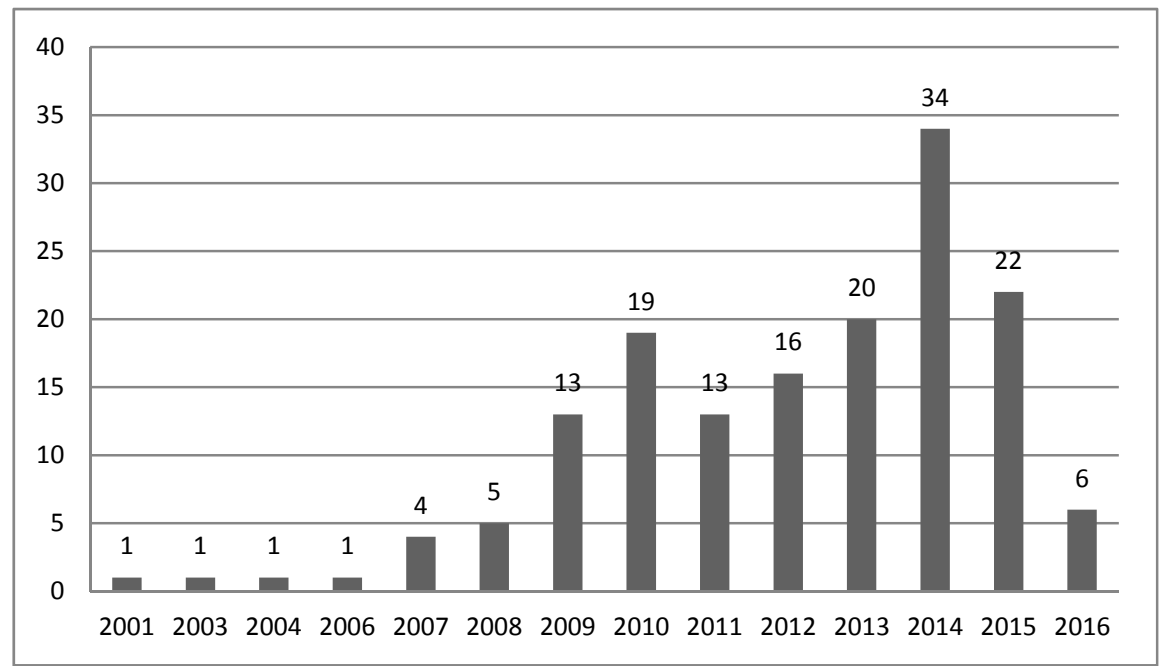

Fig. 2. Dispersion of articles during different years 


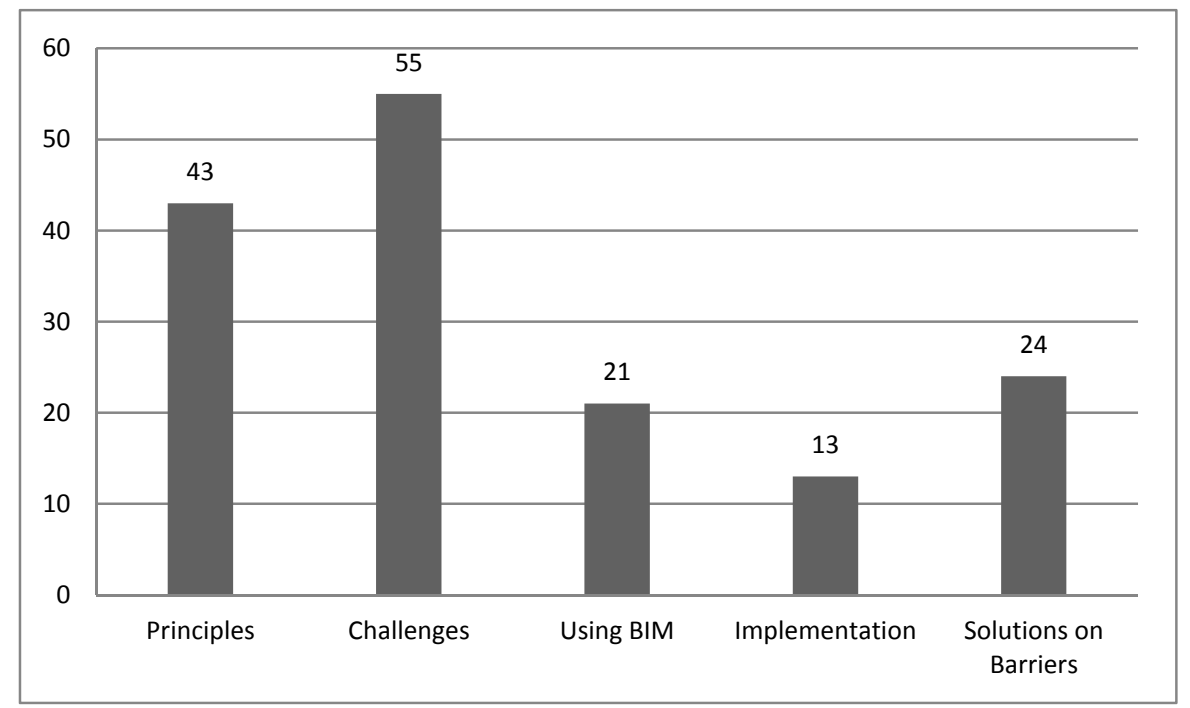

Fig. 3. Categorized by different subjects

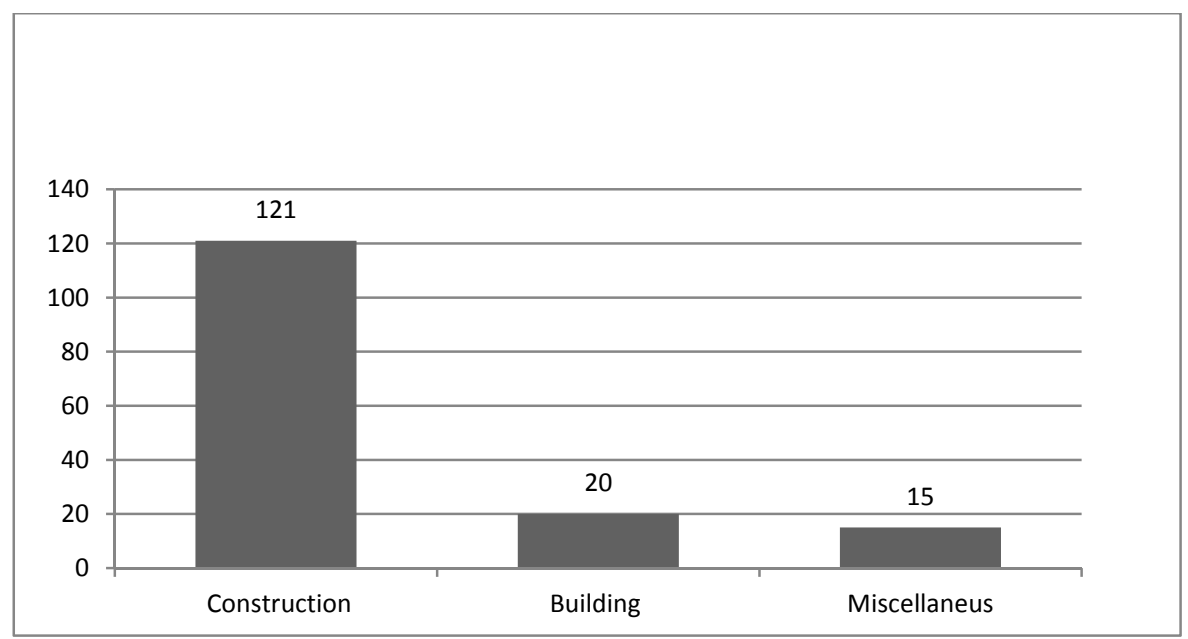

Fig. 4. Categorized by applied domains

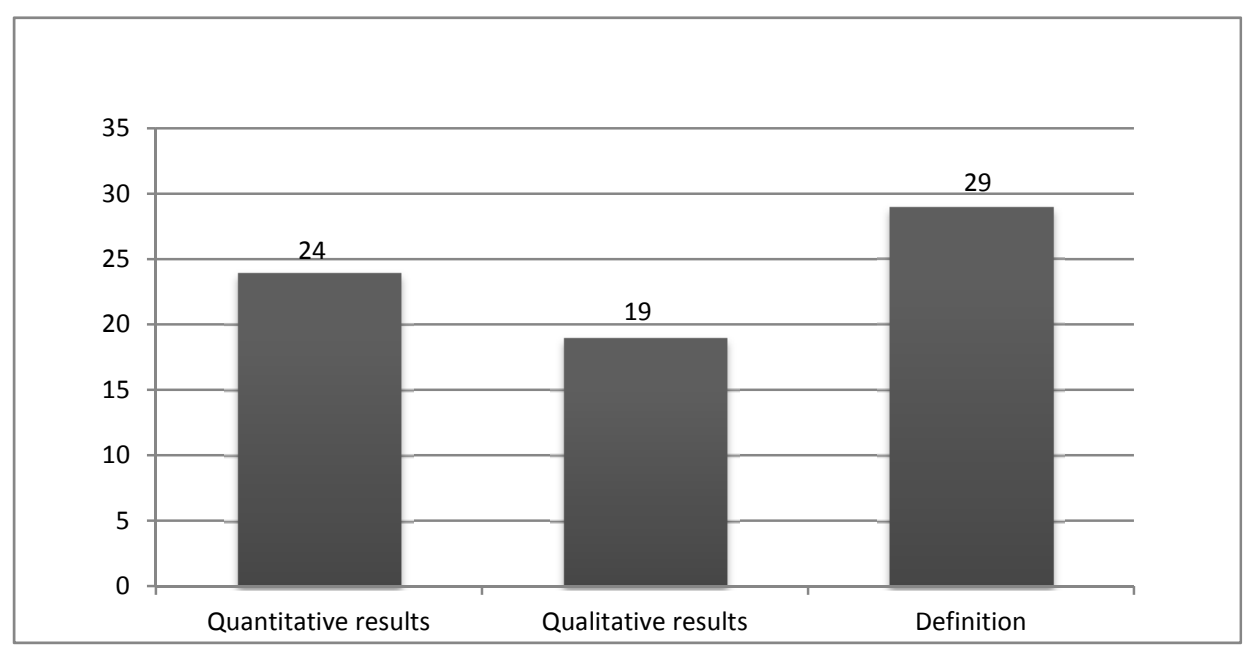

Fig. 5. Categorized by type of articles (qualitative results, quantitative analyses and those focusing on definitions, concepts and principles) 


\section{Discussion and Conclusion}

In this study, the trend of studies conducted in the field of IPD approach all over the world, is explored. According to the conducted investigations, the major source of this newly born method is the USA; so that till 2012, the most volume of articles was developed in this country. First instructions on formulating IPD in the construction industry have been invented since 2007 in this country, too. Other countries such as European countries, China (Lee, 2013), Iran and Australia have also conducted different studies in this field; particularly since 2013 till now, they have increased significantly. In recent years, particularly in 2014, researchers have paid more attention to the IPD concept, and most of them tried to localize it, by evaluating conditions, environment and laws of their countries. It seems that the obtained results can be divided into three time periods as follows:

- $\quad$ Studies from 2001 to 2009: During these years, most researches are focused on basics, principles and definitions of the IPD method, and are more focused on introducing IPD to industries.

- Studies from 2010 to 2012: During this time period, lessons learned about IPD implementation and also investigating contracts from the feasibility viewpoint for IPD implementation are considered.

- Studies from 2013 till now: Following the development of the IPD principles, these studies have evaluated challenges of this newly born method and also presented solutions for them.

In recent years, USA has had major contribution in implementing IPD and most of the conducted case studies were in this country. In these case studies, which most of them are performed by AIA, significant results were obtained. Including that flexibility of teams and common decisions made during different stages of the project, have been effective in saving time significantly. Also, they minimized change orders (O’Connor Jr., 2009). In fact, at the time of disagreement, a special meeting is hold among different stakeholders and it is tried to dissolve the issue through suitable talks. One of the reasons of fetching up such meetings, is the presence of different stakeholders and high rate of their participation (Zhang and Li, 2014). Asian and European countries have tried to define principles and basics of IPD, and also what it will bring with its implementation in such countries. Indeed, it can be said that IPD approach at any condition and situation, needs several investigations and adaptation with governing situation. The high number of articles evaluated barriers of IPD, is a proof of this claim. High degree of saving costs is also one of the cases considered in case studies, for example in a health project with 100 million dollar total cost, IPD implementation was associated with nearly 9 million dollar saving in costs (Sive, 2009). Some of the benefits of implementing IPD includes, Early participation of project key stakeholders leads to earlier completion of the project and more savings in projects (Ghassemi and Becerik-Gerber, 2011), the number of change of orders is reduced (Collins and Parrish, 2014), better implementation of risk management based on energy (Lee, 2013), in a project in San Francisco, early participation of project stakeholders resulted to reduction of change of orders up to $0.1 \%$ of construction costs (Becerik-Gerber et al., 2010). Also, IPD has been evaluated in gas and oil extraction projects and it is shown that its implementation in these projects has resulted in reduction of financial and contract problems (Al Subaih, 2015). One of the important discussed cases in some of articles was comparing IPD with other available traditional methods in performing projects; and in most of the cases, superiority of IPD over other methods is evident. In Cardinal Glennon Children's Hospital in San Luis, United States, the barrier of lack of familiarity of employers and contractors with IPD, caused deciding to use traditional contracts for the beginning, but holding education courses, used a four-sided integrated contract (AIA, 2012).

BIM is a tool for better and more systematic implementation of IPD principles along the project life cycle. In several articles, this issue and solutions of adapting and coordinating these two with each other are investigated, particularly during recent years, this important issue has been increased, significantly (Franklin and Tobin, 2010).

In this study, the trend of studies in the field of IPD was evaluated. 156 articles from different scientific databases were collected and evaluated. In the content of studied articles, different aspects of IPD was evaluated, including definitions, advantages, disadvantages, challenges, and superiorities of this method relative to traditional methods. IPD can provide a significant opportunity for participating agencies. But before any real action, the risks and advantages of using it should be understood clearly by members of the organizations and managers (AIA, 2012).

Owners of complex projects should evaluate it, to see if it is suitable for their projects (Ashcraft, 2011). Before selecting the IPD method, any organization should be very careful in selecting team and type of contract and work groups, and follow the principles of it (AIA, 2007). The project of constructing Walter Cronkite School of Journalism, in Phoenix, United States, they decided to implement IPD by maintaining the principles of design and construction contracts and the project completed on time and without high costs (AIA, 2012).

This study highlights the necessity of wider studies in the field of IPD as an important issue. This study presented an inclusive classification of IPD approach through grouping the most important criteria in the construction industry. The IPD method needs various backgrounds for its implementation in different countries, so empowerments and limitations of IPD implementation all over the world should be evaluated according to the conditions of each country.

Using IT technologies in implementing IPD is very important. With the increasing development of technology, the IPD progress in the field of sharing information and online communication is also increasing. Online communications by accurate software causes reduction of changes and duplications; therefore it will be accompanied with major savings in project costs and time. Also, one can achieve various models to improve the IPD method as much as possible, through evaluating construction management and risk management in different case projects. Different group decisions are among important cases that should be considered by group works, developing these models in future studies of researchers can pave the road for IPD implementation in other countries. In addition, this study has analyzed the main research areas in the field of IPD, and has identified 
research fields and future opportunities. The results of this study, determine future research studies more widely and more accurately. Here, different domains of construction have been classified comprehensively. For future studies, researchers can examine these fields, separately. On the other hand, in this study we can perform statistical factor analysis methods.

\section{References}

Abdirad, H. (2015). Advancing in Building Information Modeling (BIM) Contracting: Trends in the AEC/FM Industry. Architectural Engineering Institute Conference, ASCE, 1-12.

Abdirad, H. and Pishdad-Bozorgi, P. (n.d.). Trends of Assessing BIM Implementation in Construction Research. In Computing in Civil and Building Engineering 2014, 496-503.

Abdirad, H. and Pishdad-Bozorgi, P. (2014a). Developing a Framework of Metrics to Assess Collaboration in Integrated Project Delivery. 50th Annual International Conference Proceedings, 1-9.

Abdirad, H. and Pishdad-Bozorgi, P. (2014b). Trends of Assessing BIM Implementation in Construction Research. Computing in Civil and Building Engineering, 496-503. https://doi.org/10.1061/9780784413616.053

AIA. (2007). Integrated Project Delivery, a Guide. AIA, $1-57$.

AIA. (2012). IPD Case Studies. American Institute of Architects, (March), 1-114.

Al Subaih, A. (2015). Integrated Project Delivery: A Paradigm Shift for Oil and Gas Projects in the UAE and the Middle East Region. Oil and Gas Facilities, 4(4), 064-077. https://doi.org/10.2118/171722-PA

Alp, N. and Vonwerssowetz, N. F. J. (2013). Integrated project development as applied to public projects. 2013 Proceedings of PICMET 2013: Technology Management in the IT-Driven Services, 1769-1773.

Alrashed, F. and Asif, M. (2015). Climatic Classifications of Saudi Arabia for Building Energy Modelling. Energy Procedia, 75, 1425-1430. https://doi.org/10.1016/j.egypro.2015.07.245

Anonymous. (2015). The American Institute of Architects (AIA) Releases Multi-Party Agreement for Integrated Project Delivery. Report Information from ProQuest December, 1-3.

Arjmandi, A. (2011). Integrated Project Delivery and Compare deals available. Civil Engineering Conference, Semnan, Iran, 1-7.

Ashcraft, H. (2009). Integrated Project Delivery: Optimizing Project Performance. OwnersPerspective.org, 16-21.

Ashcraft, H. W. (2011). IPD Teams: Creation, Organization and Management. Howard W. Ashcraft Hanson Bridgett LLP 425 Market Street, 26th Fl. San Francisco, CA, 30.

Autodesk. (2008). Autodesk Whitepaper: Improving Building Industry Results through Integrated Project Delivery and Building Information Modeling. Autodesk Whitepaper, 12.

Azari, R., Kim, Y., Ballard, G., and Cho, S. (2014). Starting From Scratch: A New Project Delivery Paradigm. Construction Research Congress, ASCE, 2276-2285.
Azhar, N. (2014). Integrated Construction Project Delivery System in the U.S. Public Sector: An Information Modeling Framework. A Dissertation Submitted in Partial Fulfillment of the Requirements for the Degree of DOCTOR OF PHILOSOPHY, Published by ProQuest LLC, 1-263.

Azhar, N., Kang, Y., and Ahmad, I. U. (2014). Factors influencing integrated project delivery in publicly owned construction projects: An information modelling perspective. Procedia Engineering, 77, 213-221. https://doi.org/10.1016/j.proeng.2014.07.019

Bach, M. (2014). The Project Coach: The new Role of the Project Manager for the Future Due to the News Tools Like Building Information Modeling, Integrated Project Delivery, Last Planner and Others. Construction and Building Research, 43-48. https://doi.org/10.1007/978-94-007-7790-3_6

Baiden, B. K., and Andrew DF Price. (2011). The Effect of Integration on Project Delivery Team Effectiveness. International Journal of Project Management, 29(2), 129-136.

Ballobin, K. (2008). New Standard Contracts for Integrated Project Delivery : An Analysis of Structure, Risk, and Insurance. Two Wisconsin Circle Chevy Chase, Maryland 20815 301/961-9800, 1-23.

Bao, J. (2013). The implementation of the Lean Construction BIM Based on IPD Model. Journal of Science and Technology Management Research, 1-7.

Barben, B., Casey, C., Dubowski, N., and Miller, J. (2010). A Case Study for the Use of Integrated Project Delivery and Building Information Modeling for the Analysis and Design of The New York Times Building. A Thesis in Architectural Engineering Submitted to the Faculty of The Pennsylvania State University, The New York Times Building, 1-459.

Bast, J. (1994). Research Methods in Behavioral Science and Education (N. Talegha). Arian Publishing, Tehran.

Basu, R., Little, C., and Millard, C. (2009). Case Study: A Fresh Approach of the Balanced Scorecard in the Heathrow Terminal 5 Project. Measuring Business Excellence, 13(4), 22-33.

Bazargan, A. (1997). Research Methods in Behavioral Sciences. AGH.

Becerik-Gerber, B., D. Des, and Kent, D. C. (2010). Implementation of Integrated Project Delivery and Building Information Modeling on a Small Commercial Project. International Journal of Project Management, 1-6.

Bilbo, D., Bigelow, B., Escamilla, E., and Lockwood, C. (2015). Comparison of Construction Manager at Risk and Integrated Project Delivery Performance on Healthcare Projects: A Comparative Case Study. International Journal of Construction Education and Research, 11(1), 40-53. https://doi.org/10.1080/15578771.2013.872734

Brady, T., and Davies, A. (2010). From Hero to Hubris-Reconsidering the Project Management of Heathrow's Terminal 5. International Journal of Project Management, 28(2), 151-157.

Brennan, M. (2011). Integrated project delivery: a normative model for value creation in complex military medical projects. Submitted in Partial 
Fulfillment of the Requirements for the Degree of Doctor of Philosophy in Architecture in the Graduate College of the University of Illinois at Urbana-Champaign, 1-325.

Brioso, X. (2015). Integrating ISO 21500 Guidance on Project Management, Lean Construction and PMBOK. Procedia Engineering, 123, 76-84. https://doi.org/10.1016/j.proeng.2015.10.060

Bryde, D., Broquetas, M., and Volm, J. M. (2013). The project benefits of building information modelling (BIM). International Journal of Project Management, 31(7), 971-980. https://doi.org/10.1016/j.ijproman.2012.12.001

Bygballe, L. E., Dewulf, G., and Levitt, R. E. (2015). The interplay between formal and informal contracting in integrated project delivery. Engineering Project Organization Journal, 5(1), 22-35. https://doi.org/10.1080/21573727.2014.992014

Caldwell, N., Roehrich, J., and Davies, A. (2009). Procuring Complex Performance in Construction: London Heathrow Terminal 5 and a Private Finance Initiative Hospital. Journal of Purchasing and Supply Management, 15(3), 178-186.

Cao, D., Wang, G., Li, H., Skitmore, M., Huang, T., and Zhang, W. (2015). Practices and effectiveness of building information modelling in construction projects in China. Automation in Construction, 49(PA), 113-122. https://doi.org/10.1016/j.autcon.2014.10.014

Chan, A. P. C., Scott, D., and Chan, A. P. L. (2004). Factors Affecting the Success of a Construction Project. Journal of Construction Engineering and Management, 130(1), 153-155. https://doi.org/10.1061/(ASCE)0733-9364(2004)130: 1(153)

Chan, A. P., Chan, D. W., and Ho, K. S. (2003). Partnering in construction: critical study of problems for implementation. Journal of Management in Engineering, 19(3), 126-135.

Chan, A. P., Chan, D. W., and Yeung, J. (2010). Relational Contracting for Construction Excellence. Spon Press, London.

Cody, S. E. (2015). The Integration of Project Delivery in the Construction Industry. Rochester Institute of Technology, Rochester, NY 14623, USA ABSTRACT, 1-11.

Cohen, J. (2010). Integrated project delivery: Case studies. Sacramento, CA, The American Institute of Architects California Council, 248-254.

Collins, W. and Parrish, K. (2014). The Need for Integrated Project Delivery in the Public Sector. Construction Research Congress, 719-728.

Cooley, L. and Cholakis, P. (2013). Efficient Project Delivery: BIM, IPD, JOC, Cloud Computing and More. Journal of Architectural Engineering Technology, 2(1), 1-5. https://doi.org/10.4172/2168-9717.1000107

Cox, T., Kenig, M., Allison, M., Wight Kelley, S., and Stark, M. (2011). Primer on Project Project Delivery. The American Institute of Architects, 1-13.

Dal Gallo, L., O’Leary, S. T., and Louridas, L. J. (2009). Comparison of integrated project delivery agreements. Hanson Bridgett LLP, San Francisco,
CA, 1-6.

Darrington, J. (2011). Using a design-build contract for Lean Integrated Project Delivery. Lean Construction Journal, 85, 91.

Darrington, J., and Lichtig, W. . (2010). Rethinking the "G" in GMP: why estimated maximum price contracts make sense on collaborative projects. Constr.Lawyer, 30(2), 1-12.

Do, D., Ballard, G., and Tillmann, P. (2015). The Application of Target Value Design in the Design and Construction of the UHS Temecula Valley Hospital. Project Production Systems Laboratory. University of California, Berkeley.

Duke, P., Higgs, S., and McMahon, W. R. (2010). Integrated Project Delivery: The Value Proposition An Owner's Guide for Launching a Healthcare Capital Project via IPD. KLMK Group, LLC-February 2010, 1-51.

El Asmar, M. and Hanna, A. S. (2012). Comparative Analysis of Integrated Project Delivery (IPD) Cost and Quality Performance. Proceedings of the $C I B$ W78 2012: 29th International Conference -Beirut, Lebanon, 17-19 October, 152-161.

El Asmar, M., Hanna, A. S., and Loh, W.-Y. (2013). Quantifying Performance for the Integrated Project Delivery (IPD) System as Compared to Established Delivery Systems. Journal of Construction Engineering and Management, 1-14. https://doi.org/10.1061/(ASCE)CO.1943-7862.000074 4.

El Asmar, M., Hanna, A. S., and Loh, W.-Y. (2015). Evaluating Integrated Project Delivery Using the Project Quarterback Rating. Journal of Construction Engineering and Management, 142(1), 1-13. https://doi.org/10.1061/(ASCE)CO.1943-7862.000101 5

Erkessousi, N. El. (2010). How Integrated Project Delivery is an Advantage to the Danish Building Industry, and how it can be executed. 7th Semester Autumn Term, 1-46.

Fish, A. (2011). Integrated project delivery: the obstacles of implementation. MASTER OF SCIENCE Department of Architectural Engineering and Construction Science College of Engineering, B. S., Kansas State University, 2011A, 1-52.

Fish, A. and Keen, J. (2011). Integrated Project Delivery: The Obstacles of Implementation. Manhattan: Master Dissertation, Kansas State Universsity, 90-97.

Francom, T., El Asmar, M., and Ariaratnam, S. T. (2014). Using Alternative Project Delivery Methods to Enhance the Cost Performance of Trenchless Construction Projects. Construction Research Congress 2014, 1219-1228.

Franklin, D. L. and Tobin, J. (2010). Integrated Project Delivery: Next-Generation BIM for Structural Engineering. Conference Information Structures Congress 2010, Orlando, Florida, United States. https://doi.org/http://dx.doi.org/10.1061/41130(369)25 4

Franz, B. and Leicht, R. (2012). Initiating IPD Concepts on Campus Facilities with a "Collaboration Addendum." Construction Research Congress, 61-70.

Gallstedt, M. (2003). Working Conditions in Projects: 
Perceptions of Stress and Motivation among Project Team Members and Project Managers. International Journal of Project Management, 21, 449-455.

Garcia, A. J., Mollaoglu-Korkmaz, S., and Miller, V. D. (2014). Progress Loops in Interorganizational Project Teams: An IPD Case. In Construction Research Congress 2014: Construction in a Global Network, 2011-2020.

https://doi.org/10.1061/9780784413517.176

Ghassemi, R. and Becerik-Gerber, B. (2011). Transitioning to Integrated Project Delivery : Potential barriers and lessons learned. Lean Construction Journal, 32-52.

Gokhale, S. (2011). Integrated Project Delivery Method for Trenchless Projects. ICPTT 2011: Sustainable Solutions For Water, Sewer, Gas, And Oil Pipelines, 604-614. https://doi.org/10.1061/41202(423)66

Goldberg, D. E., Holland, R. J., and Wing, S. W. (2012). $\mathrm{GIS}+\mathrm{BIM}=$ Integrated Project Delivery @ Penn State. Proceedings of the 13th Int. Conf. on Information Technology in Landscape Architecture, 524-530.

Hall, D., Algiers, A., Lehtinen, T., Levitt, R. E., Li, C., and Padachuri, P. (2014). The Role of Integrated Project Delivery Elements in Adoption of Integral Innovations. EPOC 2014 Conference, 1-20.

Hampson, K. and Kraatz, J. (2013). Modelling, collaboration and integration: A case study for the delivery of public buildings. Proceedings of the 19th CIB World Building Congress: Construction and Society, 1-12.

Hanks, N. M. (2015). Investigation into the effects of project delivery methods on LEED targets. University of San Francisco USF, Scholarship Repository, Master's Projects Theses, 1-45.

Hanna, A. S. (2016). Benchmark Performance Metrics for Integrated Project Delivery. Journal of Construction Engineering and Management, 4016040(9). https://doi.org/10.1061/(ASCE)CO.1943-7862.000115 1.

Harrison, A. M., Alarcón, K. R. M., and F, L. (2016). Exploring performance of the integrated project delivery process on complex building projects. International Journal of Project Management, 34, 1089-1101.

Harty, J. and Laing, R. (2009). Drivers for change in construction procurement and its impact on management. Proceedings-2009 2nd International Conference in Visualisation, VIZ 2009, 138-143. https://doi.org/10.1109/VIZ.2009.53

Hasan, S. W. (2010). Evaluation Of Project Delivery Methods For Trenchless Construction. The University of Texas at Arlington in Partial Fulfillment of the Requirements for the Degree of MASTER OF SCIENCE IN CIVIL ENGINEERING, 1-50.

Hassan, M. E. (2013). Assessing the impact of lean/integrated project delivery system on final project success. Mason Archival Repository Service Http://mars.gmu.edu, 1-241.

Hatem, D. J. (2008a). Design Responsibility in Integrated Project Delivery: Looking Back and Moving Forward. Donovan-Hatem LLP Counselors at Law, 1-24.

Hatem, D. J. (2008b). Design Responsibility in Integrated
Project Delivery: Looking Back and Moving Forward. Donovan-Hatem LLP Counselors at Law, 1-21.

Hess, R. (2009). B.I.M. Solving the Problems in Design-to-Construction Implementation That We Have Created? Proceedings of the 78th Annual SEAOC Convention, San Diego, USA, 475-486.

Hickethier, G., Tommelein, I. D., and Lostuvali, B. (2013). Social network analysis of information flow in an ipd-project design organization. IGLC-21, July 2013 | Fortaleza, Brazil, 319-328.

Hornstein, H. A. (2014). The integration of project management and organizational change management is now a necessity. International Journal of Project Management, https://doi.org/10.1016/j.ijproman.2014.08.005

Ilozor, B. D., and Kelly, D. J. (2012). Building Information Modeling and Integrated Project Delivery in the Commercial Construction Industry: A Conceptual Study. Journal of Engineering, Project, and Production Management, 2(1), 23-36.

Integrated Workshop. (2007). Integrated Project Delivery: First Principles for Owners and Teams. Outcomes of the 3xPT Strategy Group Integrated Project Delivery Workshop, 1-16.

Jackson, M. A. (2011). Integrated project delivery-reviews related issues and the case for integrated project delivery. [Part 1, Video]. Northern California: Hanson Bridgett.

Jalaei, F., and Jrade, A. (2015). Integrating building information modeling (BIM) and LEED system at the conceptual design stage of sustainable buildings. Sustainable Cities and Society, 18, 95-107. https://doi.org/10.1016/j.scs.2015.06.007

Jayasena, H. S., and Senevirathna, N. S. (2012). Adaptability of integrated project delivery in a construction industry. Proceedings of World Construction Symposium 2012: Global Challenges in Construction Industry, Colombo, Sri Lanka, 188-195.

Jones, B. (2014). Integrated project delivery (IPD) for maximizing design and construction considerations regarding sustainability. Procedia Engineering, 95(Scescm), 528-538. https://doi.org/10.1016/j.proeng.2014.12.214

Jung, W., Ballard, G., Kim, Y., and Han, S. (2012). Understanding of Target Value Design for Integrated Project Delivery with the Context of Game Theory. Construction Research Congress, ASCE, 556-563.

Kahvandi, Z., Saghatforoush, E., Alinezhad, M., and Preece, C. (2016). Analysis of Research Trends on Benefits of Implementing Integrated Project Delivery (IPD). In International Conference on Civil, Mechanical Engineering and Construction Management (CMC 2016), Kuala Lumpur, Malaysia.

Kelly, D. J. and Ilozor, B. D. (2013). A Pilot Casual Comperative Study of Project Performance Metrics: Examining Building Information Modeling (BIM) and Integrated Project Delivery (IPD). The Built and Human Environment, 6, 82-106.

Kent, D. C., and Becerik-gerber, B. (2010). Understanding Construction Industry Experience and Attitudes toward Integrated Project Delivery. Journal of Construction Engineering and Management, $136(8)$, 
https://doi.org/10.1061/ASCECO.1943-7862.0000188

Kiani, I. and Khalili Ghomi, S. (2013). The Barriers and Implementation of Building Information Modeling (BIM) based on Integrated Project Delivery (IPD) In the Construction Industry. Author Profiles for This Publication

at: https://www.researchgate.net/publication/272789025.

Kihong Ku, Dd. (2009). The Core of Eden: A Case Study on Model-Based Collaboration for Integrated Project Delivery. Construction Research Congress, 969-978.

Kim, K., and Teizer, J. (2014). Automatic design and planning of scaffolding systems using building information modeling. Advanced Engineering Informatics, 28(1), 66-80. https://doi.org/10.1016/j.aei.2013.12.002

Klotz, L. and Horman, M. (2010). Counterfactual analysis of sustainable project delivery processes. Journal of Construction Engineering and Management, 136(5), 595-605.

https://doi.org/10.1061/(ASCE)CO.1943-7862.000014 8

Korkmaz, S., Swarup, L., and Riley, D. (2013). Delivering Sustainable, High-Performance Buildings: Influence of Project Delivery Methods on Integration and Project Outcomes. Journal of Management in Engineering, 29(0742-597X), 71-78. https://doi.org/10.1061/(ASCE)ME.19435479.0000114

Kraatz, J., Sanchez, A., and Hampson, K. (2014). Digital Modeling, Integrated Project Delivery and Industry Transformation: An Australian Case Study. Buildings, 4(3),

453-466. https://doi.org/10.3390/buildings4030453

Kulkarni, A., Rybkowski, Z. K., and Smith, J. (2012). Cost comparison of collaborative and ipd-like project delivery methods versus competitive non-collaborative project delivery methods. IGLC 2012 - 20th Conference of the International Group for Lean Construction, 1(979), 1-10.

Lahdenperä, P. (2012). Making sense of the multi-party contractual arrangements of project partnering, project alliancing and integrated project delivery. Construction Management and Economics, 30(1), 57-79. https://doi.org/10.1080/01446193.2011.648947

Lee, C. (2013). Implemenation of Integrated Project Delivery on Department of Navy Military Construction Projects. Published by ProQuest LLC, August, 1-162.

Lee, H. W., Anderson, S. M., Kim, Y., and Ballard, G. (2014). Advancing Impact of Education , Training , and Professional Experience on Integrated Project Delivery. Practice Peridocal on Structural Design and Construction, 19(February), 8-14. https://doi.org/10.1061/(ASCE)SC.1943-5576.000019 0.

Lee, H. W., Oh, H., Kim, Y., and Choi, K. (2015). Quantitative analysis of warnings in building information modeling (BIM). Automation in Construction, 51, 23-31. https://doi.org/10.1016/j.autcon.2014.12.007

Lee, H. W., Tommelein, I. D., and Ballard, G. (2013). Energy-Related Risk Management in Integrated Project Delivery. Journal of Construction Engineering and Management, 139(12), 1-8.

Li, Y. and Taylor, T. R. (2011). The Impact of Design Rework on Construction Project Performance. The 29th International Conference of the System Dynamics Society. Washington, DC.

Lichtig, W. (2006). The Integrated Agreement for Lean Project Delivery. Constr. Law, 26, 25.

Lu, T., Lu, X., and Viljanen, M. (2015). A New Method for Modeling Energy Performance in Buildings. Energy Procedia, 75, 1825-1831. https://doi.org/10.1016/j.egypro.2015.07.154

Lu, W., Fung, A., Peng, Y., Liang, C., and Rowlinson, S. (2014). Cost-benefit analysis of Building Information Modeling implementation in building projects through demystification of time-effort distribution curves. Building and Environment, 82, 317-327. https://doi.org/10.1016/j.buildenv.2014.08.030

Ma, M., Li, C. X., and Meng, Y. (2014). Study on the Application of BIM Technology in Construction Projects under IPD Mode. ICCREM 2014: Smart Construction and Management in the Context of New Technology, ASCE, 229-236. https://doi.org/10.1061/9780784413777.028

Macdonald, J. and Mills, J. (2013). An IPD Approach to Construction Education. Australasian Journal of Construction Economics and Building, 13(2), 93-103.

Manning, R. T. (2012). Field Project Challenges, Benefits, and Risks Associated with Integrated Project Delivery and Building Information Modeling. The Faculty of the Graduate School of The University of Kansas in Partial Fulfillment of the Requirements for the Degree of Master's of Science, 1-47.

Matthew, B. and Miles, A. (1984). Qualitative date analysis:A source book of new methods london. Educational Evaluation and Policy Analysis.

McCurley, T. and Powell, S. (2015). Power of IPD: Is integrated project delivery truly a transformative delivery model? Report Information from ProQuest, $1-4$.

McKew, H. (2007). Integrated Project Delivery. AIA California Council 2007, 26(1), 1-12.

Michael, K., Markku, A., Boyd, B., Luciana, B., and Colella, C. (2010). Integrated Project Delivery For Public and Private Owners. Retrieved from http://www.agc.org/galleries/projectd/IPD\%20for $\% 20$ Public\%20and\%20Private\%200wn, 1-40.

Mihic, M., Sertic, J., and Zavrski, I. (2014). Integrated Project Delivery as Integration between Solution Development and Solution Implementation. Procedia-Social and Behavioral Sciences, 119, 557-565. https://doi.org/10.1016/j.sbspro.2014.03.062

Mohadesi, J. (1997). Research Guide. I. Islamic Propagation Office, Qom, Ed.

Mollaoglu-Korkmaz, S., Miller, V. D., and Sun, W. (2014). Assessing key dimensions to effective innovation implementation in interorganizational project teams: an Integrated Project Delivery case. Engineering Project Organization Journal, 4(1), 17-30. https://doi.org/10.1080/21573727.2013.855895

Monteiro, A., Meda, P., and Pocas Martins, J. (2014). Framework for the coordinated application of two different integrated project delivery platforms. Automation in Construction, 38, 87-99. 
https://doi.org/10.1016/j.autcon.2013.11.003

Mossman, A., Ballard, G., and Pasquire, C. (2010). Lean Project Delivery-innovation in integrated design and delivery. Construction Research Information Magazine, $1-25$. https://doi.org/10.13140/2.1.2713.2804

Nawi, M. N. M., Haron, A. T. H., Hamid, Z. A. H., Kamar, K. A. M., and Baharuddin, Y. (2014). Improving Integrated Practice through Building Information Modeling-Integrated Project Delivery ( BIM-IPD) for Malaysian Improving Integrated Practice through Building Information Modeling-Integrated Project Delivery (BIM-IPD) for Malaysian Industr. Malaysia Construction Research Journal (MCRJ), 15(2), 1-15.

Nejati, I., Javidruzi, M., and Mohebifar, A. H. (2014). Feasibility of Using an Integrated Project Delivery (IPD) in Mass Housing Collaborative Projects. Advances in Environmental Biology, 8(25), 211-218.

Nofera, W., Korkmaz, S., and Miller, V. (2011). Innovative Features of Integrated Project Delivery Shaping Project Team Communication. EPOC 2011 Conference, 1-16.

O’Connor Jr., P. J. (2009). Integrated Project Delivery: Collaboration through New Contract Forms. Faegre and Benson, LLP, 1-59.

Overbeek, S., Janssen, M., and van Bommel, P. (2012). Designing, formalizing, and evaluating a flexible architecture for integrated service delivery: Combining event-driven and service-oriented architectures. Service Oriented Computing and Applications, 6(3), 167-188. https://doi.org/10.1007/s11761-011-0100-0

Parfitt, M. K., Holland, R. J., and Solnosky, R. L. (2013). Results of a pilot multidisciplinary bim-enhanced integrated project delivery capstone engineering design course in architectural engineering. AEI 2013: Building Solutions for Architectural Engineering Proceedings of the 2013 Architectural Engineering National Conference, 43-52. https://doi.org/10.1061/9780784412909.005

Perdomo, J. L., and Cavillin, H. (2014). Transforming Building Design through Integrated Project Delivery in Architectural and Engineering Education. Construction Research Congress 2014, 359-368.

Perdomo, J. L., Truijens, M., Hou, L., Wang, Y., and Zhou, Y. (2014). Integrating Augmented Reality with Building Information Modeling: Onsite construction process controlling for liquefied natural gas industry. Automation in Construction, 40, 96-105. https://doi.org/10.1016/j.autcon.2013.12.003

Perlberg, B. (2009). Contracting for Integrated Project Delivery: ConsensusDOCS. The 48th Annual Meeting of Invited Attorneys, 1-10.

Pishdad-Bozorgi, P. (2016). Case Studies on the Role of Integrated Project Delivery (IPD) Approach on the Establishment and Promotion of Trust. International Journal of Construction Education and Research, 13(2), 102-124. https://doi.org/10.1080/15578771.2016.1226213

Pishdad-Bozorgi, P., Hamzanlui Moghaddam, E., and Karasulu, Y. (2013). Advancing Target Price and Target Value Design Process in IPD Using BIM and
Risk-Sharing Approaches. 49th ASC Annual International Conference, Associated Schools of Construction, 1-10.

Pishdad-Bozorgi, P., and J. Beliveau, Y. (2016). Symbiotic Relationships between Integrated Project Delivery (IPD) and Trust. International Journal of Construction Education And Research, 12, 179-192. https://doi.org/http://dx.doi.org/10.1080/15578771.20 15.1118170

Pishdad-Bozorgi, P. and J.Beliveau, Y. (2016). A Schema of Trust Building Attributes and Their Corresponding Integrated Project Delivery Traits. International Journal of Construction Education and Research, 22(2), 142-160. https://doi.org/10.1080/15578771.2015.1118171

Popic, Z. and Moselhi, O. (2014). Project Delivery Systems Selection for Capital Projects Using the Analytical Hierarchy Process and the Analytical Network Process. Construction Research Congress, 1339-1348.

Qiang, M., Wen, Q., Jiang, H., and Yuan, S. (2015). Factors governing construction project delivery selection: A content analysis. International Journal of Project Management, 33(8), 1780-1794. https://doi.org/10.1016/j.ijproman.2015.07.001

Rached, F., Hraoui, Y., Karam, A., and Hamzeh, F. (2014). Implementation of IPD in the Middle East and its Challenges. Proceedings International Group for Lean Construction. Olso, Norway, Proceedings IGLC-22, 293-304.

Rahim, S. A., Nawi, M. N. M., and Nifa, F. A. A. (2015). Improving Construction Industry through Integrated Project Delivery (IPD). BinaTECH, 1, 27-32.

Rahman, N. A., Abdullah, S. R. S., Kofli, N. T., Tasirin, S. M., Kamarudin, S. K., and Jahim, J. M. (2013). Enhancement in Monitoring for Integrated Project Implementation. Procedia Social and Behavioral Sciences, 102(Ifee 2012), 92-99. https://doi.org/10.1016/j.sbspro.2013.10.718

Raisbeck, P., Millie, R., and Maher, A. (2010). Assessing integrated project delivery: A comparative analysis of IPD and alliance contracting procurement routes. 26th Annual Conference of the Association of Researchers in Construction Management, ARCOM 2010, 1019-1028.

Rawat, S., and Divekar, B. R. (2014). Assessing Integration between Project Management with NPD Process in Heavy Industrial Components Industry and Developing a Framework to Align them. Procedia Economics and Finance, 11(14), 726-736. https://doi.org/10.1016/S2212-5671(14)00236-6

Roe, C. L. (2014). Project Management and Systems Engineering In An Ipd Environment Charles. The Johns Hopkins University Applied Physics Laboratory Johns Hopkins Road, Laurel, Maryland 20723-6099, 1063-1068.

Salami, E. (2012). Introduction of IPD and likely Impacts on Pretender Cost Management in Ghana. University of Applied Science Stuttgart Drees and Sommer, Switzerland, 1-5.

Sanz-Calcedo, J. G., Gonzalez, A. G., Lopez, O., Salgado, D. R., Cambero, I., and Herrera, J. M. (2015). Analysis on Integrated Management of the 
Quality, Environment and Safety on the Industrial Projects. Procedia Engineering, 132, 140-145. https://doi.org/10.1016/j.proeng.2015.12.490

Seed, W. R. (2014). Integrated Project Delivery Requires A New Project Manager. Proceedings IGLC-22, 1447-1459.

Shahhosseini, V. (2013). Barriers of Implementation of Integrated Project Delivery in IRAN, 2.

Shahhosseini, V., Hajarolasvadi, H., and Joshaghani, A. J. (2014). Integrated Project Delivery Using Building Information Modeling: A New Approach in Sustainable Construction. Researchgate.Net, 1-11.

Shahhosseini, V., Shakeri, E., Hajarolasvadi, H., and Naderi, A. N. (2014). Integrated Project Delivery, A New Approach in Management and Implementation of Civil Projects. 9th Internationl Project Management Conference, IRAN, 1-13.

Shane, J. S. and Gransberg, D. D. (2010). A Critical Analysis of Innovations in Construction Manager-at-Risk Project Delivery. Construction Research Congress, 827-836.

Singleton, M., and Hamzeh, F. (2011). Implementing Integrated Project Delivery on Department of the Navy construction projects. Lean Construction Journal, 17-31.

Sive, T. (2009). Integrated Project Delivery : Reality and Promise A Strategist's Guide to Understanding and Marketing IPD. Marketing Research, (800), 1-30.

Smith, V. R. R., Castro-Lacouture, D., and Oberle, R. (2009). Effects of the Regulatory Environment on Construction Project Delivery Method Selection. Construction Research Congress, (404), 211-218.

Sommer, A. F., Dukovska-Popovska, I., and Steger-Jensen, K. (2013). Barriers Towards Integrated Product Development-Challenges From a Holistic Project Management Perspective. International Journal of Project Management, 32(6), 970-982.

Son, H., Lee, S., and Kim, C. (2015). What drives the adoption of building information modeling in design organizations? An empirical investigation of the antecedents affecting architects' behavioral intentions. Automation in Construction, 49(PA), 92-99. https://doi.org/10.1016/j.autcon.2014.10.012

Tan, Y. C. (2006). A Handbook for Improving Real Estate Project Delivery in Malaysia: Analysis, Comparison and Selecting the Best Method. Submitted to the Department of Architecture in Partial Fulfillment of the Requirements for the Degree of Master of Science in Real Estate Development, 1-65.

Tatum, C. B., and Luth, G. P. (2012). Integrating Structural and Construction Engineering. Construction Research Congress 2012, ASCE, 1301-1310.

Tenah, K. A. (2001). Project delivery systems for construction: An overview. Cost Engineering (Morgantown, West Virginia), 43(1), 30-36.

Thomsen, C. (2007). Managing Integrated Project Delivery-Concepts and Contract Strategies. CMAA, 35, 1-52. https://doi.org/10.1093/carcin/bgu172

Thomsen, C. (2009). Integrated Project Delivery: An overview. CMAA, 1-28.

Tillmann, P., Ballard, G., Tzortzopolous, P., and Formoso, C. (2012). How integrated governance contributes to value generation-Insights from an IPD case study. IGLC 2012-20th Conference of the International Group for Lean Construction, 1-10.

Treiblmaier, H., and Filzmoser, P. (2010). Exploratory factor analysis revisited: How robust methods support the detection of hidden multivariate data structures in IS research. Information and Management, 47(4), 197-207.

Turkulainen, V., Ruuska, I., Brady, T., and Artto, K. (2014). Managing project-to-project and project-to-organization interfaces in programs: Organizational integration in a global operations expansion program. International Journal of Project Management, 33(4), 816-827. https://doi.org/10.1016/j.ijproman.2014.10.008

Volk, R., Stengel, J., and Schultmann, F. (2014). Building Information Modeling (BIM) for existing buildings Literature review and future needs. Automation in Construction, $\quad 38, \quad 109-127$. https://doi.org/10.1016/j.autcon.2013.10.023

Volker, L., and Klein, R. (2010). Architect Participation in Integrated Project Delivery: the Future Mainspring of Architectural Design Firms? Gestão and Tecnologia de Projetos, 5(3), 39-58. https://doi.org/10.4237/gtp.v5i3.181

Voss, M. (2012). Impact of customer integration on project portfolio management and its success-Developing a conceptual framework. International Journal of Project Management, 30(5), 567-581.

https://doi.org/10.1016/j.ijproman.2012.01.017

Wamelink, J. W. F., Koolwijk, J. S. J., and van Doorn, A. J. (2012). Integrated project delivery: The designer as integrator, 2 BT-Ma, 1026-1037.

Wang, J. (2008). Integrated Project Delivery. The University of Cincinnati, Master Of Science, 1-16.

Wickersham, J. (2009). Legal and Business Implications of Building Information Modeling (BIM) and Integrated Project Delivery (IPD). Construction, 1-9.

Xue, X. L., Shen, Q. P., and Ren, Z. M. (2010). Critical Review of Collaborative Working in Construction Projects: Business Environment and Human Behaviors. Journal of Management in Engineering, 26(4), 196-208.

Yalcinkaya, M., and Singh, V. (2015). Patterns and trends in Building Information Modeling (BIM) research: A Latent Semantic Analysis. Automation in Construction, 59, 68-80. https://doi.org/10.1016/j.autcon.2015.07.012

Zhang, L., Cheng, J., and Fan, W. (2015). Party Selection for Integrated Project Delivery Based on Interorganizational Transactive Memory System. Journal of Construction Engineering and Management, $\quad$ 142(3), 4015089. https://doi.org/10.1061/(ASCE)CO.1943-7862.000106 8

Zhang, L. and Li, F. (2014). Risk/Reward Compensation Model for Integrated Project Delivery. Inzinerine Ekonomika-Engineering Economics, 25(5), 558-567.

Zhang, L., Li, Y., and Wu, Q. (2013). Evaluation on Collaborative Satisfaction for Project Management Team in Integrated Project Delivery Mode. Journal of The Institution of Engineers (India): Series A, 94(2), 
109-115. https://doi.org/10.1007/s40030-013-0041-z

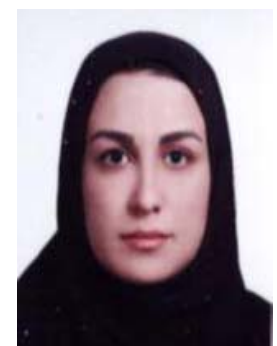

Zahra Kahvandi is an MSC in the Project and Construction Management (PCM) from Mehrealborz Institute of Higher Education (MIHE). She is the gold member of the Construction and Project Management Clinic (CPMC) within the institute. Her research interests include Construction Management, Building Information Modelling (BIM) and Integrated Project Delivery (IPD).

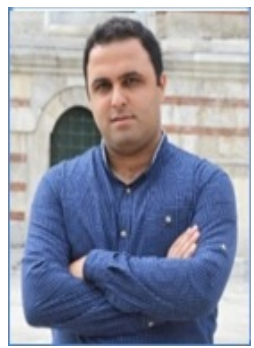

Dr. Ehsan Saghatforoush is an Assistant Professor in the Project and Construction Management (PCM) Department at Mehrealborz Institute of Higher Education (MIHE). $\mathrm{He}$ is the founder and instructor of the Construction and Project Management Clinic (CPMC) within the institute. His research interests include Construction Management, Building Information Modelling (BIM), Integrated Project Delivery (IPD), Constructability, Operability and Maintainability concepts (COM).

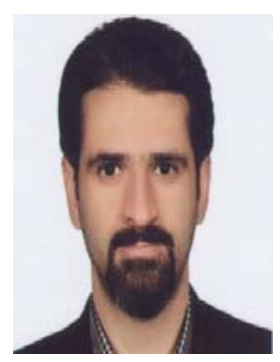

Mahdi Alinezhad is an MSC in the Project and Construction Management (PCM) from University of Tehran (UT). He is the gold member of the Construction and Project Management Clinic (CPMC) within the institute. His research interests include Construction Management, Building Information Modelling (BIM) and Integrated Project Delivery (IPD).

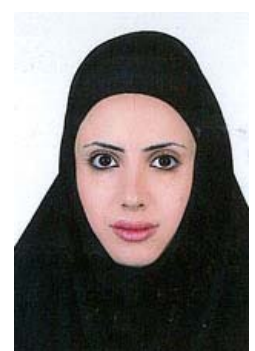

Farimah Noghli is an MSC in the Project and Construction Management (PCM) from Mehrealborz Institute of Higher Education (MIHE). She is the gold member of the Construction and Project Management Clinic (CPMC) within the institute. Her research interests include Construction Management, Building Information Modelling (BIM) and Integrated Project Delivery (IPD). 